\title{
MARKETING PODNIKU V DOBĚ KRIZE
}

\section{Miroslav Merenda}

\section{Klíčová slova:}

marketing, ekonomická krize, zákazník, průzkum trhu, poptávka, poradenská firma, oživení, efekt, zisk

\section{Key words:}

marketing, economic crisis, consumer, market research, demand, konsultant firm, resurgence, effect, gain

\begin{abstract}
Abstrakt
Článek se zabývá marketingem podniku v době krize. Konkurenční výhody jsou omezeny. Zaměření na zákazníka je ještě důležitější než v časech příznivějších. Udržování silných značek zůstává jedním z nejlepších způsobů, jak omezit riziko podniku a zefektivnit jeho výkon. Cílem marketingu je stálý prodej se ziskem, který je vyjádřením společenského uznání výrobní a obchodní činnosti každého podnikatele. Podnikání může být úspěšné jen tehdy, když jsou zákazníci spokojeni a opakují své nákupy.
\end{abstract}

\begin{abstract}
Article deal with marketing company at the time crisis. Competitive advantage ave restraint. Intent on consumer is yet major than in time favourable. Maintainance strong brands stays one of the best way how limit hazard company and zefektivnit his achievement.The aim marketing is to sell with permanent profit, which is an expression of social recognition of productive and business activities of each entrepreneur. Business can be successful only if customers are satisfied and thein purchases are repeated.
\end{abstract}

\section{Úvod}

Vývoj marketingu je nerozlučně spjat s rozvojem trhu. S tím se postupně rozvíjel i soubor činností, které zabezpečovaly výrobu a prodej zboží podle tržních podmínek. Tento soubor aktivit byl pojmenován souhrnným názvem marketing.

Současný marketing již představuje dynamický, integrovaný komplex funkcí, který umožňuje efektivně řešit problémy spojené s podnikáním na rozvinutém trhu.

Podstatu marketingu se pokoušejí více či méně zdařile vystihnout desítky různých definic:

- Marketing je integrovaný komplex činností, zaměřených na trh,

- Cílem marketingu je stálý prodej se ziskem, který je vyjádřením společenského uznání výrobní a obchodní činnosti každého podnikatele.

Marketing jako soubor aktivit slouží k zabezpečení marketingové koncepce podnikání, která se zakládá na principu trvalé orientace dodavatelského podniku na aktivní uspokojování potřeb spotřebitelů, kterému podnik přizpůsobuje zaměření procesů vývoje, výroby a prodeje zboží.

Cílem článku je poukázat na to, že dnešní firmy musí usilovat o uspokojování potřeb zákazníků způsobem, který zákazníkům nejvíce vyhovuje, o minimalizaci množství času a 
energie, jež zákazníci vynakládají na vyhledávání, objednávání a převzetí zboží a služeb. Podniky se musí vyrovnat, a to obzvlášt' v době ekonomické krize, se dvěma základními silami ovlivňujícími podnikatelskou činnost s tendencí ke stírání rozdílů mezi produkty téže kategorie na straně nabídky a s tlakem zákazníků na přizpůsobování produktů podle individuálních preferencí na straně poptávky.

\section{Marketing v době ekonomické krize}

Slovo krize je odvozeno od řeckého slova „Krisis“- a znamená rozhodnutí. Jde o bod obratu k lepšímu nebo horšímu, rozhodný moment či situace, ve kterých nastává rozhodující změna. V čínštině se pro slovo krize používá dvou znaků: první znamená „,nebezpečí“ a druhý „prríležitost“. Takže vyjděme z toho, že nejde jen o hrozbu, ale také o příležitost, a že záleží na našem rozhodnutí.[ 1]

Je důležité si uvědomit změny, ke kterým dochází, a to nejen v závislosti na krizovém období. Současná doba"přináší' informované zákazníky, kteří si mohou najít nepřeberné množství informací na internetu či prostřednictvím kontaktů ze sociálních sítí. To znamená nejen nové informační zdroje, ale i nové prostředky prodeje.

Konkurenční výhody jsou omezeny, protože konkurenti jsou schopni rychleji a snadněji napodobovat či kopírovat nové produkty. Zaměření na zákazníka je ještě důležitější než $\mathrm{v}$ časech prŕżnivějších. Je nutné reagovat na změny chování spotřebitelů a tomu přizpůsobit nabídku i komunikaci ve vztahu ke konkurenci.

Krize se může stát zdrojem př́ležitostí. Marketéři musejí počítat se složitým vývojem i do budoucna. Nemohou se spolehnout na to, že krize či recese skončila a že mají několik let času, než přijde další. [2]

Ekonomická krize ochromila sektor marketingu snad jako nikdy před tím. Extrémní podmínky na trhu si pro úspěch vyžadují extrémní řízení firmy. Na tom se asi shodne většina manažerů zasažených podniků. Které marketingové nástroje používat během krize? To v současné době řeší mnoho marketérů.

Současná ekonomická situace se u většiny firem projevuje snížením obchodu, snížením obratu. Pokles nastává díky tomu, že klesá kupní síla obyvatel, a nebo (což celé situaci předchází) změna chování spotřebitele. Pokud kolem sebe bude spotřebitel slyšet negativní prognózy o recesi, tak velmi rychle zareaguje a začne více spořit. Bojí se totiž o svou práci. Úspory z obav jsou jedním z mechanizmů, jak vyvolat zcela záměrně ekonomickou krizi.

Prognózování by si měli nechat představitelé bank (které nakonec na krizi vydělají) jen pro sebe. Pokud bychom si představili svět bez masmédií, tak bychom ekonomickou krizi ani nepocítili. Zkrachovalo by několik bank a několik málo firem, ale propad ve světě by nebyl tak vysoký.

Ale pro běžný chod firmy je třeba se na situaci dívat jinak. Krize je vlastně to, že na trhu je o něco menší krajíc, než v minulosti a ted' se o něj musí nějak rozdělit firmy. Stane se však, že na někoho i nezbude, a nebo zbude na všechny. Takové situace lze přece využít. Jediný předpoklad je ochota riskovat. Výnos z tohoto risku je nebývalý. V době, kdy se firmy snaží uloupnout z krajíce alespoň něco na udržení své existence, jsou všechny a hlavně ty co celou dobu fungují na hraně své existence, zranitelné. Jedna menší rána by je dokázala zlikvidovat. 
V marketingové strategii je proto nutné zvolit vybrané metody pro získání klienta. Firmy ale volí většinou opačnou cestu. Snaží se o udržení toho svého zákazníka. To je samozřejmě správné. V době krize tento postup znamená"spokojení se s tím málem co se na trhu nabízí". $\mathrm{K}$ tomu, abychom konkurenci dokázali vyřadit ze hry, může být jen krůček.

První předpoklad je, dostatečné zajištění marketingových aktivit pro udržení stávajících zákazníků. Druhý předpoklad je, neomezovat marketing na získávání nových klientů.

\section{Management investic do marketingu}

Během krize je důležité než jindy uvědomit si, že loajální zákazníci jsou hlavním a trvalým zdrojem př́ijmů. Marketing není fakultativní- je nezbytný k tomu, aby se zajistily př́jmy od těchto klíčových zákazníků i ostatních. Přesto redukce podnikového rozpočtu často zasahuje marketing neproporcionálně. Náklady na marketingovou komunikaci lze snížit rychleji než výrobní náklady- a bez propouštění. Ale podniky přitom musí pečlivě rozlišovat mezi nezbytnými a nehospodárnými úsporami. Udržování silných značek zůstává jedním z nejlepších způsobů, jak omezit riziko podniku.

Podstatně omezit rozpočet je snazší za krize než v dobách prosperity. Když je v sázce přežití, lze ale také snadněji získat souhlas s revizí marketingových strategií a relokací financí. Manažeři se mohou vzepřít starým způsobům myšlení a kreativně hledat lepší řešení z hlediska potřeb zákazníků. Výzvou je vypracovat dobře obhajitelná doporučení, kde výdaje snížit, kde zachovat a kde dokonce zvýšit.

Z těchto důvodů je třeba:

1. Vyhodnotit př́ležitosti. Začněte posouzením vašich značek a produktů či služeb. Určete, které mají slabé vyhlídky na přežití, které mohou mít klesající prodej, ale lze je stabilizovat a které pravděpodobně uspějí i v krizi i po ní. Vaše strategické príležitosti budou silně záviset na tom, ke kterému segmentu vaší zákazníci patří a jak zařazují vaše produkty a služby do jednotlivých kategorií, tj.

- Nezbytné, jsou nutné pro přežití nebo jsou vnímány jako důležité pro pocit zdraví a pohody,

- Požitky jsou slabosti, jejichž bezprostřední uspokojení nákupem je považováno za ospravedlnitelné,

- Odložitelné jsou potřebné nebo žádoucí položky, jejichž nákup lze přiměřeně odložit,

- Postradatelné, jsou vnímány jako nepodstatné a neospravedlnitelné.

Vyhlídky jsou celkem dobré pro kvalitní „nezbytnosti“ prodávané „brzdícím“ zákazníkům, kteří se vzdají prvotřídních značek ve prospěch nižších cen. Značky odpovídající hodnotě mohou také oslovit „,rozmrzelé, ale trpělivé“ zákazníky, kteří dříve kupovali dražší značky. Ti se rovněž mohou více poptávat po opravárenských službách, nebot' se budou snažit např. prodloužit životnost své pračky, místo aby si koupili novou. Tam, kde jsou prŕíležitosti nejisté nebo ochabující, je čas rozloučit se s př́slušnými značkami nebo produkty. A na ty, které zůstanou by podniky měly soustředit své marketingové zdroje.

2. Přidělit zdroje s dlouhodobým výhledem. Když prodej začne klesat, podniky by neměly panikařit a měnit základní obsah značky nebo její umístění. Např́iklad obchodníci zásobují zákazníky ve střední a vyšší př́ímové skupině v segmentu „rozmrzelých, ale trpělivých“ mohou být v pokušení přejít k levnějšímu zboží. To by 
mohlo odradit loajální zákazníky. Obchodníci, kteří se odpoutají od svých zavedených produktů, mohou krátkodobě přilákat některé nové zákazníky, ale budou v oslabené pozici, až krize skončí. Nejlepší postup je značku stabilizovat.

Při volbě marketingové taktiky je důležité sledovat, jak zákazníci přehodnocují své priority, přerozdělují své rozpočty, mění značky a kategorie produktů a nově oceňují hodnotu. Proto je důležité investovat do průzkumu trhu. Jakmile krize skončí, zákazníci obnoví svou koupěschopnost, ale možná se nevrátí ke svým starým vzorcům nákupního chování. Průzkum trhu by měl zjistit, zda se zákazníci vrátí k původním značkám a produktům, zůstanou u náhradních produktů, nebo uvítají inovace.[5]

Obchodníci musejí zůstat flexibilní a přizpůsobovat se předpokladu dlouhého, těžkého útlumu, a přitom reagovat rychle, až dojde $\mathrm{k}$ obratu. To např́klad znamená mít připravenou řadu inovací, které lze rychle uvést na trh. Většina zákazníků bude ochotna zkusit nové výrobky, až se ekonomika zlepší. Firmy, které budou otálet, budou vydány na milost lépe připraveným konkurentům. Ale i v recesi mají nové produkty důležité místo. Zákazníci ,ze dne na den“, kteří mají zálibu v nových výrobcích a zážitcích, novinky ocení. Další segmenty uvítají nabídku zřejmé hodnoty ve srovnání s alternativami. A protože inovační aktivita za krize klesá, nové výrobky jsou dobře viditelné.

3. Udržovat vyrovnaný rozpočet na komunikaci. Během krize jsou marketingová oddělení pod tlakem udělat více s méně prostředky a dokazovat vysokou návratnost investic. Zpravidla se podíl rozpočtu na reklamu v rozhlase a televizi snižuje, zatímco podíl na aktivity s měřitelnějšími výsledky, jako přímý marketing či online akce, roste. Marketing na prodejních místech- např. propagace snížených cen, nebo zajímavé akce v prodejně- také obvykle nabírá na síle.

Zejména reklama na internetu je cílená a poměrně levná, a její přínos lze snadno měřit. Dalším faktorem podporujícím růst digitální inzerce je přesun zákazníků k online sociálním médiím jako je např. Facebook. Rozhlas a televize zůstávají přesto důležité pro masové spotřební zboží.

\section{Osvědčené cesty z krize}

V době krize musejí obchodníci vážit mezi úsilím snižovat náklady a zvyšovat krátkodobé prodeje na jedné straně a investovat do dlouhodobého zdraví značky na straně druhé. Toto jsou tři efektivní cesty $\mathrm{k}$ dosažení těchto cílů:

1. Zefektivnit portfolio produktů. Vzhledem ke klesající poptávce za krize by měli obchodníci redukovat nadměrnou šíri těchto produktových řad, které jsou charakterizovány př́liš mnoha okrajovými velikostmi, nebo individuálními rozdíly mezi modely. Př́íliš široké produktové řady vyžadují značné marketingové náklady a vážou zdroje i provozní kapitál v nízkoobrátkových zásobách. Zefektivnění portfolia produktů neznamená zastavit inovace. Inovativní zlepšování klíčových produktů přiláká pozornost zákazníků a motivuje $\mathrm{k}$ nákupům.

Nové tržní podmínky si vyžadují časté přehodnocování, predikce poptávky po jednotlivých položkách produktové řady, nebot' nákupní zvyklosti zákazníků se posunují. Tak „brzdící“ zákazníci obětují rozmanitost ve prospěch jednoduchosti a nižších cen nezbytností a požitků. 
V př́padě nákupu zboží dlouhodobé spotřeby, který nelze odložit, „rozmrzelí, ale trpělivi““ zákazníci přejdou k modelům, které zdůrazňují hodnotu spíše než lepší vlastnosti.

2. Zvýšit cenovou dostupnost. „Brzdící“ a zejména „rozmrzelí, ale trpělivi““ zákazníci budou hledat co nejvýhodnější nákupy. Proto podniky budou stále více soutěžit cenou. V této době jsou akční slevy, které vyžadují od zákazníků malé úsilí a vrací hotovost ihned v místě prodeje, mnohem efektivnější než reklama s pozdějším zpětným získáním hodnoty jako například soutěže či nabídky poštou. Mnozí obchodníci budou muset zvýšit frekvenci a rozsah svých akčních slev. Zároveň musejí pečlivě monitorovat jak zákazníci vnímají normální cenovou úroveň. Nadměrné akční slevy vedou zákazníky k tomu, aby revidovali svá očekávání o cenách směrem dolů a mohou tak ohrozit ziskovost v období zotavení, kdy se ceny vracejí k „normálu“.

3. Posílit důvěru zákazníků. Zneklidnění zákazníci vidí známé, důvěryhodné značky a produkty jako bezpečnou volbu v perných dobách. Uklidňující sdělení, která posilují emoční vazbu na značku a demonstrují empatii, jsou proto důležitá. Empatická sdělení musí být podpořena akcemi dokazujícími, že firma je na straně zákazníků. Jestliže se prodej snižuje, to poslední je přesunout problém na ně omezením kvality a zvýšením ceny. Programy loajality by měly odměnit nejen ty, kteří utrácejí hodně, ale také ty, kteří kupují často menší množství. Maloobchodníci by měli vzdělávat zákazníky, jak výhodně nakupovat a ušetřit peníze.

\section{Př́íprava na oživení}

Firmy, které dokázaly během krize zaměřit pozornost na potřeby zákazníků, budou mít dobrou pozici, až se vrátí lepší časy. Musí ale zároveň pochopit, jak se postoje lidí mohou po krizi změnit, aby byly sto nabízet produkty odpovídající potřebám nových zákaznických segmentů. Když většina krizí skončí, chování zákazníkủ se vrátí k“normálu“ za jeden až dva roky. Nicméně po výraznějších poklesech může zvýšený pocit zranitelnosti trvat u zákazníků ještě déle. Čím hlubší a delší krize, tím větší je možnost, že v postojích a hodnotách zákazníků dojde k hlubokým změnám.

Důsledky krize zpravidla nebývají tak extrémní, ale současná krize je neobyčejně vážná a důvěra spotřebitelů i víra v ekonomiku jsou rekordně nízké. Proto je tu možné, že postoje a chování zákazníků utvořené během krize budou setrvávat i poté, co krize skončí.

Tento pohled na současnou krizi přináší dvě ponaučení:

1. Ukázněnost v marketingové strategii a průzkumu trhu během krize a schopnost hbitě reagovat na změny $\mathbf{v}$ poptávce- bude obchodníkům nadále prospívat, až se ekonomika zotaví.

2. Obchodníci by se už nyní měli připravit na možný dlouhodobý posun v hodnotách a postojích spotřebitelů. Otřes $\mathrm{z}$ poklesu a $\mathrm{z}$ toho, co $\mathrm{k}$ němu vedlo, může zrychlit předchozí trendy $\mathrm{k}$ ústupu od materializmu a $\mathrm{k}$ udržitelnému rozvoji, doprovázené větším očekáváním sociální odpovědnosti podniků a odporem k cynickému marketingu, který jedná se zákazníky jako s bezduchými, mechanickými figurkami. Ti budou stále více požadovat, aby byznys jednal v nejlepším zájmu jejich i společnosti, a zohlední praktiky firem ve volbě své značky. Pro obchodníky by bylo riskantní, kdyby tato měnící se očekávání ignorovali.[3] 


\section{Efektivní marketing v době ekonomické krize}

Krize postavila marketingové manažery před jedno zásadní měřítko. Tím je efektivita jejich výkonu. Dosáhnout v krizi dobrého výsledku v marketingu znamená jednak dnes a denně př́močaře a jednoduše podporovat prodej, jednak nezapomínat na dlouhodobou hodnotu značky a pověsti firmy. Být toho schopen s rozumnými náklady vyžaduje tvořivostinovativní myšlení a ekonomické myšlení- cit a soudnost ve vztahu k nákladům. Tyto schopnosti tak tvoří kompetenční model marketingového manažera za krize.[7]

\subsection{Marketing poradenské firmy $v$ době krize}

Poradenství je službou, jejíž vnímání se v době krize polarizuje. Na jednu stranu je vnímána jako zbytný luxus, z druhé strany jako cenný zdroj znalostí a schopností nezbytných pro zvládnutí potíží nebo jejich obrat v príiležitost.

Marketingové profesionální služby považuji postavit na pěti pilířích:

1. Excelentní volba cílových skupin, tj. neztrácet čas s potenciálními klienty bez jasné motivace k využití poradenských služeb.

2. Zřetelný profil služeb- jasně a úderně komunikovatelný obsah a hodnota služby.

3. Zvýšená pozornost kontaktům a vztahům, tj. nelitovat prostředků na udržení a rozvoj pozitivního vztahového rámce.

4. Orientace na moderní komunikační technologie, tj. oslovení businessových nebo zájmových komunit, charakteristických motivovaností a proaktivitou.

5. Neztrácet pozornost pokrmovému období, tj. pamatovat na marketingový mix cílený pro období oživení a konjunktury.

Je zřetelné, že marketing poradenské firmy vobdobí ekonomické krize by měl být „dvojohniskový“, tj. zaměřen jak do aktuálního období, tak do budoucna. Čím více se tato dvě období liší, tím větší pozornost $\mathrm{k}$ integritě marketingu vyžaduje. To je dalším paradoxem marketingu v době krize.[4]

\section{Závěr}

Složitá ekonomická situace znamená pro firmy především nutnost efektivnější kontroly jejich investic. I marketing je takovou investicí, a proto je důležité, aby byl cílený a měřitelný.

Těžké období v ekonomice je přesně tím okamžikem, kdy marketing hraje klíčovou roli. Pokud je efektivní a přináší výsledky, nemá smysl se ho zbavovat. A přece jsou to právě marketingové rozpočty, které se seškrtávají jako první. Než se ale k tomuto kroku rozhodneme, měli bychom zvážit:

1. Přinese to krátkodobý efekt, nebo dlouhodobý zisk?

Studie britské konzultační společnosti Data 2 Decisions ukázala, že firmám, které v době krize přestaly investovat do marketingu, trvalo 5 let, než se jejich výše prodejů vrátila na původní úroveň. Firmám, které v kritickém období snížily marketingové rozpočty na polovinu, to trvalo 3 roky. Co ušetříte nyní, zaplatíte mnohonásobně později, jelikož se tento krok může v delším horizontu negativně odrazit na našich prodejích. 
2. Co upevní a ochrání firemní značku?

Spotřebitel v současné době ze všeho nejvíc potřebuje důvěryhodnost. Potřebuje věřit v nastavený finanční systém, který jej do budoucna zabezpečí, a musí také důvěřovat výrobku a jeho značce. Protože s omezenými finančními prostředky si spotřebitel nemůže dovolit nesprávnou volbu produktu nebo služby, spíše nakoupí značku, kterou si spojuje s kvalitou a dlouhodobou prítomností na trhu.

3. Jak udržet, či dokonce posílit tržní podíl?

Právě ekonomické poklesy jsou nejvhodnějším obdobím na posílení tržního podílu a upevnění značky firmy. Pokud společnost omezí marketing, vytrácí se ze zorného pole spotřebitele. To je př́ležitost pro bystrého konkurenta a jeho šance vyplnit tento uvolněný tržní podíl zvýšenou marketingovou aktivitou.

4. Jak docílit, aby byl marketing efektivní, cílený a měřitelný?

Právě nyní by firmy měly požadovat lepší měřitelnost marketingu a vědět, kolik jim vynesla každá investovaná koruna. V této oblasti narážejí tradiční média na určitá omezení, avšak internetový marketing umožňuje velmi přesně měřit výsledky a návratnost investic. Navíc lze internetovou reklamu velmi účinně cílit. Firmy mohou jednoduše identifikovat svého zákazníka, přizpůsobit své sdělení přímo jemu a zároveň cíleně zasáhnout širokou masu uživatelů.

\section{Literatura:}

[1] KOTLER, P.; WONG, V.; SAUNDERS, J.; ARMSTRONG, G. Moderní marketing. 4. vyd. Praha: Grada Publishing, 2007. 1041 s. ISBN 978-80-247-1545-2.

[2] VYSEKALOVÁ, J. a MIKEŠ, J. Image a firemní identita. 1. vyd. Grada Publishing, 2009. 192 s. ISBN 978-80-2790-5.

[3] QUELCH, J. A.; JOCZ, K. E. How to Marketin a Downturn, Harvard Business Review, duben 2009.

[4] KOTLER, P.; JAIN, D. C.; MAESINCEE, S. Marketing v pohybu.1. vyd. Praha: Management Press, 2007. 171 s. ISBN 978-80-7261-161-4.

[5] VAŠTÍKOVÁ, M. Marketing služeb efektivně a moderně. 1. vyd. Praha: Grada Publishing, 2008. 232 s. ISBN 978-80-247-2721-9.

[6] BOUČKOVÁ, J. Základy marketingu. 3. vyd. Praha: Vysoká škola ekonomická, 2008. 220 s. ISBN 978-80-245-1169-6.

[7] BUREŠ, I. Marketing pro firmu. 1. vyd. Praha: Management Press, 1995. 143 s. ISBN 80-85603-89-6.

\section{JEL M31}

\section{Doc. Dr. Ing. Miroslav Merenda}

Docent Katedra marketingu a obchodu

Ekonomická fakulta

VŠB- TU Ostrava

Sokolská 33

Tel.: 597322134

miroslav.merenda@vsb.cz 